\title{
原毛塊多孔度が洗, 乾毛に及ぼす影響についで
}

（第 4 報） 流下浸毛方式による場合の浸毛効率の相違について

\begin{tabular}{|c|c|c|c|c|}
\hline （昭和31年12月13日受理） & 会 & 池 & 田 & \\
\hline
\end{tabular}

\section{研 究 目 的}

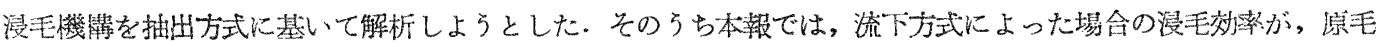
塊多孔度によってどのように相違するかを笑験的に求め, Maloard 漫毛機に打ける状熊を説明しようとした。

\section{研 究 結 果}

（1）浸毛排液の色相的性状を光電比色計を用いて検討した結果，常温水使用の塔合は透過光線の吸収に関する Lambert-Beer の法則にしたがラが，温湯使用の場合はグリース分の分離脱落分散があるためこの法則は適用さ れない.

（2）单一流下浸毛過程に拈ける流出液の濃度の変化を観察した結果, 流出初期には水及び晹使用の耐場合とも 多孔度の小なるほど濃厚液を排出し, 次第に無色に近づいていくそそして流出中期以後に括いては湯使用の場合順 位は逆となり，多孔度の大なるほど濃厚液を継続的汇排出する傾向が認められる。

(3) 所要時間を考慮に大れないで（これは费際工程の状態ではないが）流下方式による場合の多孔度による浸 毛效率 $\left(\eta_{f}\right)$, 注剂比 $\left(d_{f}\right)$ の相違を求めた結果, 両者とも多孔度の小なるほど大である。

（4）実際丁程に即して, 流出時間を規定して湘定比較した結果, 多孔度, 使用水温度が效率に対して大きな影

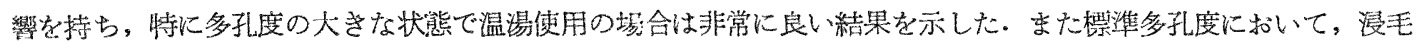
時閏を变化した場合についての効率の変化傾向をも求めた。

（5）標準多孔度の場合について，原毛量の多少による効率の相違を検討した結果，排出絕対量は原毛量の增加 にともない多くなることはもちろんであるが，これを効率的煌算すると大差ない。しかしある程度以上原毛量が 多くなり羊毛畨が厚くなると, 規定時間內での漫毛效摔はきわめて悪くなるので, 浸毛機に拈ける給毛過多は不適 当であり，後続の洗毛部門の負担を大とすることになる.

\section{1. 緒言}

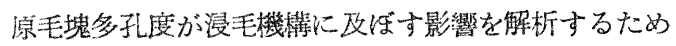

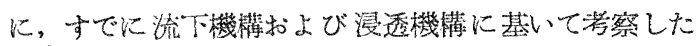

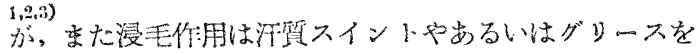
め含めたジーク分を対爱とした広義の抽战作用である とみなすことができる。抽出とは液体溶郕をもって固体 または液体原料を观理して，可溶性成分寸なわち抽犋を

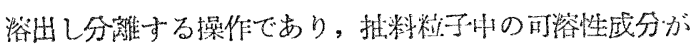

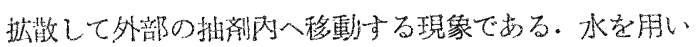
て可溶性スイント分を溶解排出する場合はももろんとし て, 温晹を用いて全非一ク分を刘象として浸㫣伅理した 埸合には，融点以上であることによりグリース分蛅の
中に分㒕脱落分散してくる。そしてやはり扰散的に外部 浸鄅中に出てくる。またこの埸合，スイント洗毛法の 原理に示すよ5に，炭酸力り分が促進的役割を夥すであ ろう.したがって温湯傅用により全ヨーク分を対象とし

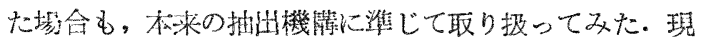
在奏際に行われている漫毛方法として二つの埸合があ りまず英式の Whites Steeping Machineあるいは

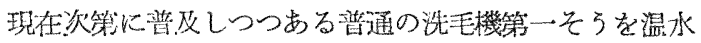
のみとして浸もを行う方法は, 多分にこの抽出機構に 基いているむのであり，また仏式の埸合の Maloard Steeping Bowl に拀いては, 濾過機構に潐じた流下方 式に基く広義の抽出作用ということができる.

そこで本墊及び次報に拈いては，供給原毛塊多孔度の

* The Effect of Wool Porosity on the Scouring and Drying Process. Part 4: Steeping Efficiency of Maloard Steeping Machine.

些 A. Ikeda, H. Sanuki, Member. 東京幽工大学 
大小によって，この搔出機構及び效率がいかに罣なるか を実験的に求めてみた結果を報告する。すで第 1 報に おいてて流下機構に基いて流出量，流出速度等について考 察したが，本報では同様に流下方式によった埸含，その 流泏液（すなわち浸毛排液）の性状が多孔度によってい かに買なるかを求めた結果を述べ，次報においては漫せ き方式によった場合の測定結果をしるし，さらに続報に 扰いてエーテル溶剤を用いて本来の意昧の純料抽出処理 を行った場会，多孔度による效率の相違及び抽出理論に 基く洘察を述ベる。

\section{2. 漫毛排液の色相に関する予備的検定}

以卜各項の奏験において，水及び湯を用いて浸毛排出 液を得て，その漫毛效率につき考察するのであるが，尖 験方法のうらその効率の算出手段として, もし各採取液 が透週光線の吸収に関する Lambert-Beer の法則

$\log I_{t} / I_{0}=\log T=-k c d$ (1)

ただし

$I_{0}$ : 入射するときの光の强さ

$I_{\ell}:$ 液雷通過後の光の強さ

$c:$ 溶液 濃度

$d:$ 液雷の長さ

$k$ : 波長, 温度, 浴媒等によってさまる常数

$\boldsymbol{T}$ ：透過率

にしたがらならば非常に好都合であり，あらかじめ作製 した稤準グラフを用いることによって，各採取液の光線

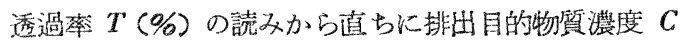

（g％）を知ることがでさる。そして各採取液の全重量

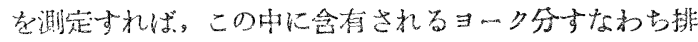
出された物犋量を知ることができ，浸毛效率が算出され ることになる。

そこでまず本項では，果してこの法則が適用されるか どらかを检定するために，採取液湛度と光線透過交との 関係を蒸発乾固法及び光電比色訢を用いて求めた。すな わら土砂等の微細固形不純物の付着していない試料羊毛 の告皇量 (3〜10 g ) を採取し，十分に開毛し多孔度を きわめて大として，ビ一カ中で常温 $\left(20 \pm 1^{\circ} \mathrm{C}\right)$ 及び 60 $\pm 2^{\circ} \mathrm{C}$ の蒸白水 $250 \mathrm{cc}$ 中に浸せきし，そのま任琶時 間 (5〜30 min) 放監してヨーク分を排出させ，種くな 色相と濃度をもった浸毛液を得る。まずエルマ光電比色 計 5 型を使用し, 清色フィルタ波長 $(435$ 我 $480 \mathrm{~m} \mu)$ に より蒸监水をブランクとして透過等を測定し，続いて蒸 発乾固して念有固形ヨーク分を科量子る.として先に測 定して蛙いた採取液の全重量からその䀼度 $C(\mathrm{~g} \%)$ を

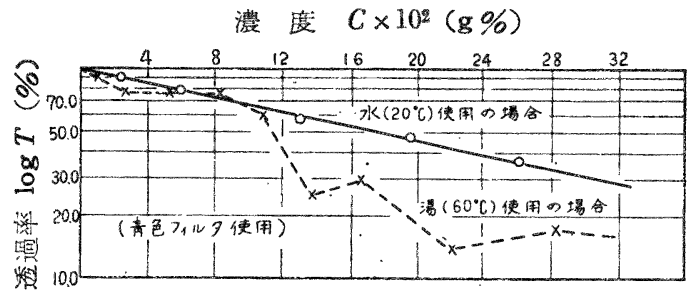

(等 1 汹) 本試料羊毛浸毛排液透過摔～涨度関係困

求めることができる。そこで片刘数グラフ用紙の対数䩜 を透過率 $I^{\prime}(\%)$ にとり，等分軸を物質鋠度 $C(\mathrm{~g} \%)$

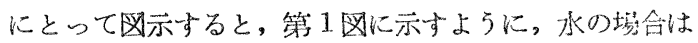
見事な值線関係が得られるが，湯の埸合は相当のはらら

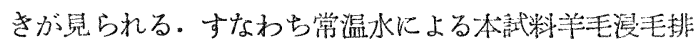
液は舫記の Lambert-Beer の法則に適合し,この棉潐 グラフを用いることによって各採取液の透過率 $T(\%)$ の読みから, 直ちに排出目的物質濃度 $C(\mathrm{~g} \%)$ を知る ことができるわけである。しかるに $60^{\circ} \mathrm{C}$ 温淐使用の場 合はこの法則にしたがわず, $T \sim C$ 間に一定の相関関係 が得られないので笑用することができない。

このよ5に水使用の場合と湯使用の場合で採取液の $T^{*}$ 〜C関䋆は一致しないがこれはこのよ5な静的漫せき 方式によった場合，常湿水によってはスイント分のみが 抽出され, 液濃度はカり塩類（炭酸力りをきとし, 塭化 カリ，硫酸カリなどつとしてのスドレート酸カリ量によ ってきまることになる。しかる湯を用いた場合にはス イント分はむらろんとして、グリ一ス分も融点以上にあ るため一部分離脱落分散されることになり，このため搡 取液はかなり白濁不透明となり，水使用の淕合と同一濃 度に就いても透過率は相当小さな值を示すことになるか らである・地湯による採取液でる加温腹過して测定す ればはとんど氷の場合と同じ直線傾间となるが，これで は排出物質量（グリース分）に譟差を生じ不都合であ る。

ゆえに以下各項に和ける浸毛效率(ク)の算出には、す ベて蒸発乾固法による通常の方法によった。

な就本報に扣いて用いた試料羊毛は徤来と同様である がそ採取に当っては特に肉腿鑑別により，よごれ，

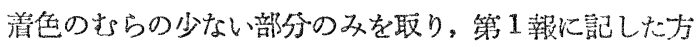
法により一様なヨーク付着部分を得た。そしてこのかり ノ羊毛は，水漫せさ及びンックスレ抽出器でェチルェ一 デル使用20回サイフォンにより別途測定の結果，原毛無 水量（含水率は $14.80 \%$ 程度）飞対して平均 $19.66 \%$ の固形ヨーク分 (スイント4.10\%，グリース $15.56 \%$ ) を含有しているから，各項任和ける原毛採取量に尤して 


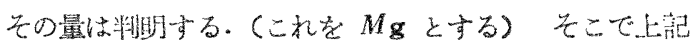
のようにして各測定に批いて挑出された固形ヨーク昰 $(\mathrm{Ng})$ を知るならば

$$
\eta=N / M \times 100 \%
$$

をもって漫毛效洠とすることができる。

\section{3. 单一流下浸毛過程における流出液の濃度 の変化}

流下漫毛方式によった境合の浸毛排液の多孔度による 性状の变化の一つとして, 流出液の濃度の時間的变化が ある、すなわち連結的に注水流下排出した場合，その流 出液は初め漂かっ色を是するが，次第に色相は希溥とな

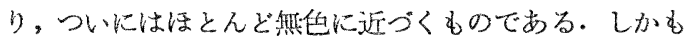
この变色過程は多孔度によって相違すると考光られるの で,この点につき解析した。

央験裝置としては, 第 1 派第 1 困に示したと同様の力 法によって, 各多孔度に作成した試料羊毛塊より水なた は湯を用いて流出液を得て，とれにつき測定した。（以 下各項に捺いて同じ）乙して本項に括いては，各測定 に括いて試料量を同一としヨーク分を均一にする必要が あるので, “恒容積の多孔度 $\left(P_{c}\right) ”$ は採用することがで

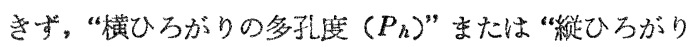
の多孔度 $\left(P_{v}\right)$ によよらねばならない。ここでは $P_{v} に$

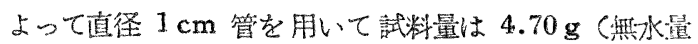
$4 \mathrm{~g} ）$ として，管下端より $9.9,13.2,19.7,39.7 \mathrm{~cm}$ 简さに冭てんし，それぞれ 60，70，80，90\%の多孔度

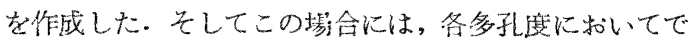
きるだけ同様な条件のむとに流下排出を行わせる澺味か ら，注水压は同一とすることが望ましいので，注水量は 試料上端面から $10 \mathrm{~cm}$ 位置を保持させた。すなおち $7.85 \mathrm{~g} / \mathrm{cm}^{2}$ の恒生流下となる。このような操作により 流出液を初滴落下より $10 \mathrm{cc}$ ずつ順次別受唯に採取し。 この扮の扔のについて濃塂を睍定した。

实験絬果とその溚䋈

多孔度 $60,70,80,90 \%$ 亿的いて, 水 $\left(22 \pm 1^{\circ} \mathrm{C}\right)$

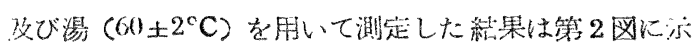
すごとくである。(米川の冬点はとれぞれ5回測定の平 均俌を示す）

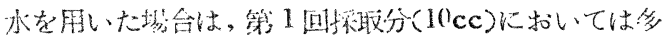

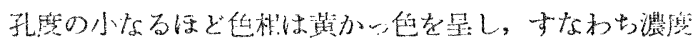
は大であり，多孔度の人となるにしたがって服次茠溥と なり， $P_{n}=90 \%$ においては汪とんど掅色は認められず

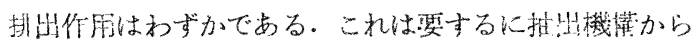

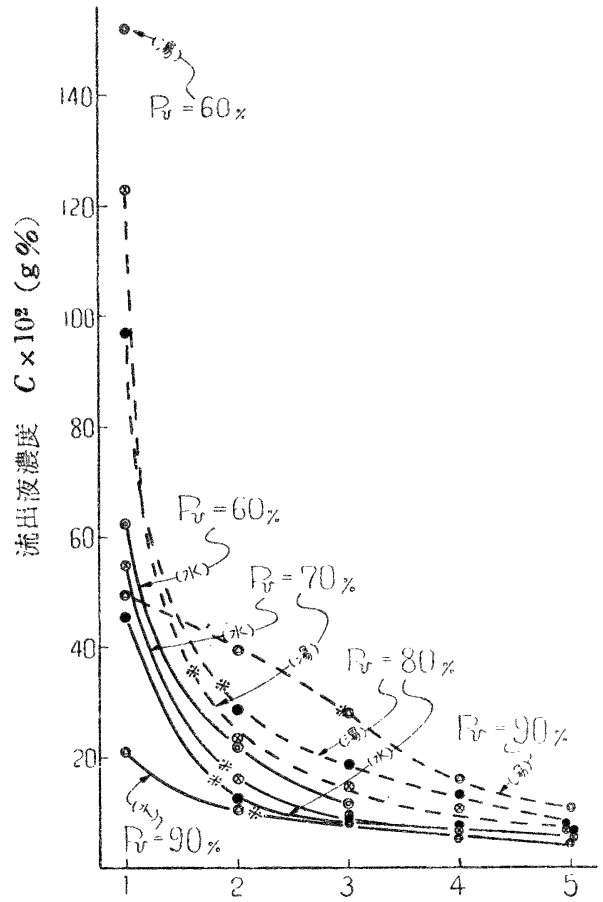

探取順位（回）

(第2四) 流下浸毛過程に指け3流山液の濃監 の变化( *印法 5 回分合液の平均值炎示吉)

み机ば滞畄時間が重要な因子であり，一定時閏漫削山に 㫼料を漫せき保持する必要があるが，本項のごとく流下 方式仁よると, $P_{v}$ の大なる場合には，毛細管系のむらむ 大きく，漫凨としての水が特大の通路を選んで急速に流 下するため效雨は悪くなる・しかるに には,第 1 報に示したごとく滞畄時開が長いので,とれた け浸毛作用は大きくなることになる。このこと関して は些驗室的な普通抽出処理に和ける手法として，簡便迅

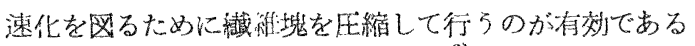
との“死控抽出法”が提案されている。高大第2 回採取

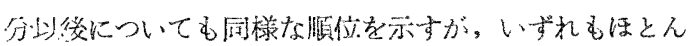

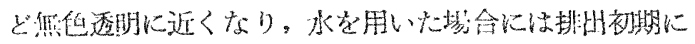
の及浸毛效果は認められても, それが永続的でないこと を知ることができる。(P $P_{v}=60 \%$ の塕合には，第4回 採取以後は孔ふさがりによ一て㵜下が少しとなり採取不 能であった）

次に湯を用いた場合には，第１回採妏分についてはい ずれも水の萝合より濃くなり、スイント分のみならずグ

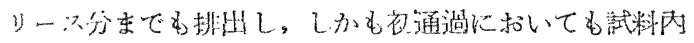

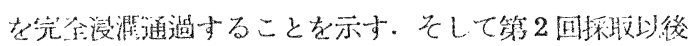

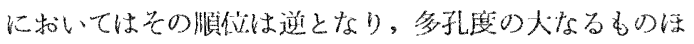
ど濃厚色を永続的に排出する。 $\left(P_{v}=60 \%\right.$ の场合には， 
第 2 回採取以後は孔ふさがりのため定温保持による採取 は不可能ですったりこれは多孔度の小なる場合には， 初回に和いて一度に相当程度排出されるために，第2回 以後では急激に溄度が低下することと，繊維の膨溜及び ヨーク尔や不純物のたい積に基く架橋現象による孔ふさ がりが多くなるので，効率を覀くすることに基因する。 これに対し $P_{v}=90 \%$ に和いては，比面が大でありしか も通渦速展が速いので，各回において粗雜ではあるが平 均した效率をあげることになる。として孔らさがりが少 なくグリース排出の阻帮がないことが大きな理由と若え られ\%。

\section{4. 所要時間を考慮しない場合の浸毛効率の 相違}

前墳に拀いて示したように, 流下方式による場合のヨ 一ク分排出の時間的変化状態は多孔度によって租逵し, なた使用水の温底によっても梋違することが明らかとな った。したがって全ヨーク分を対象とした浸毛效率も， 原毛塊の多孔度によ二て相当異なると思われるのでこ の点について湘定比較してみた。ただし縒料羊毛塊中の

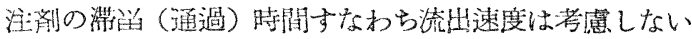
むのとする・したがって本涀定の示す結果がそのまま寒

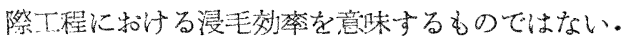

奏験方法としては，やはり $P_{v}$ によって直径 $2 \mathrm{~cm}$ 管 を脽い, 武料量は $8.22 \mathrm{~g}$ (然水量 $7 \mathrm{~g}$ ) として管下端よ b $4.3,5.7,8.5,16.8 \mathrm{~cm}$ 啇さに立てんし,60,70,80, $90 \%$ \%多孔度を作成した。そしてこの塓合は，本来の 抽仙機满にのっとって注剂比をむ算出するために。注水 量 $100 \mathrm{cc}$ として䘞期水压 $31.8 \mathrm{~g} / \mathrm{cm}^{2}$ の減圧流沃よ った。そしてこのよらな操作において

流出液量 $\quad V \mathrm{cc}$

滞坚液量 $\quad v=($ 注:水量 $-V$ ) $\mathrm{cc}$ とすれば

注剂比 $\alpha_{f}=V / v$ (3)

にて算出され，多孔度の相違による变化が求まる。

実騒法果とその教察

各多孔度の堎:合につき水及び晹を用いて，浸毛効率

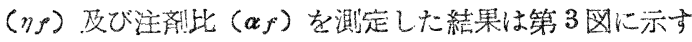
ごとくである、(ただし湯による $P_{v}=60 \%$ においては

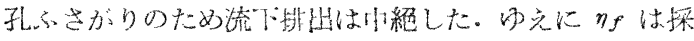
取液量平均 $66 \mathrm{cc}$ の秋ついての测定值であるが，これ

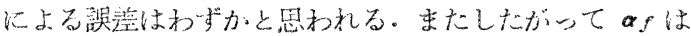
算出不可能であのた）両者の場合とも，多孔度の小な

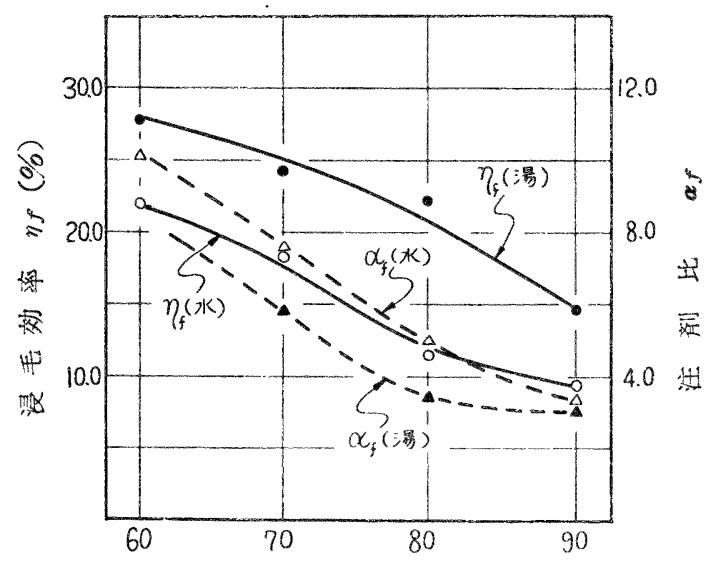

多孔度 $P_{v}(\%)$

(第 3 図) 流下浸毛方式による場会の多孔度に よる浸毛初率，注剂比の変化（ただし所要時間 を考慮しない埸合)

る泀ど排出量は多くなり效率は大となる。

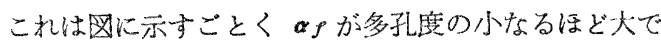
あることにもよるが，最も大きな理由は前述のごとく洲 坚時間（羊毛層通過時閪）がきわめて長く浸毛作用が促 進されるためである。

として湯を用いることによって 祦は大となるのはも

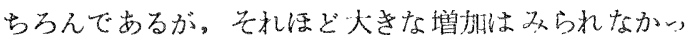
た。また af の変化比ついては, 第1 報 5 靧の排水量, 滯当水量の考察と全く同様である。

\section{5. 規定浸毛時間における多孔度による漫毛 効率の相違}

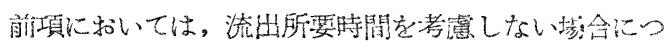
き測定考察したのであるが，実際的浸毛手段として流出 速度をあわせ洘慮した苓合には，第1報に示したごとく 多孔度の小なるほど初流出時間は長くかかり，単位時間 に执ける排地量はきわめて少量である。ゆ光に実際工程 に和いては、多孔度の小なる状態で長時聞をかけて浸毛 妈理するということは意味がなく，やはり多孔誽の大き な状態で，ラチス上に扔いて浸毛作用を受ける有限時閭 內で,くり返し連絸注水によって挑出量の增大を図っだ 方がはるかに有效であることはいうまでもなく、これが また經対必要条件となる。

そこでいまこれを明らかにするために，本項に打いて は，前項と同様な多孔度作成法によった㭶合，滰甘時間 を挸定して排出液を採取し效率を求めてみた。主なわり 实際 Maloard 浸毛機に拁いて，むる羊毛塊が浸毛作用

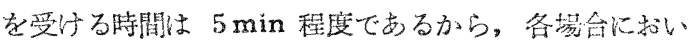


て $10 \mathrm{~g}^{\prime} \mathrm{cm}^{2}$ の恒王連続流下により，注水開始より $5 \mathrm{~min}$ 媵の流出湤を採取し，排出輩を測定し效率を求 めた。そしてこの塔合，要因として多孔度 $\left(P_{v}\right)$ ，使用 水温算 $\left(T_{e}\right)$ )の二つをとり，水準としては $P_{v-1}=60 \%$ ， $P_{v-q}=70 \%, P_{v-3}=80 \%, P_{v-4}=90 \%, T_{e-1}=22 \pm$ $1^{\circ} \mathrm{C}, T_{e-2}=60 \pm 2^{\circ} \mathrm{C}$ として, この处理采件の各組合 世につき，浸毛奻秦 $\left(\eta_{f}\right)$ 及び採取流出液量 $\left(V_{p}\right)$ を 3 回ずつ測定した。

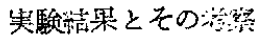

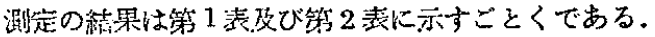

(第I表) 逨被流下浸毛方江に上る場合の規 定特間 ( $5 \mathrm{~min}$ ) に把汸吉多孔度, 注刘温度

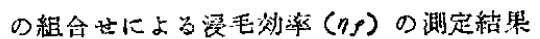

(临位 \%)

\begin{tabular}{|c|c|c|c|}
\hline 多卆度 & 注削温息 & $T_{0 \rightarrow 1}\left(22^{\circ} \mathrm{C}\right)$ & $T_{a-2}\left(60^{\circ} \mathrm{C}\right)$ \\
\hline \multirow{3}{*}{$P_{v-1}$} & \multirow{3}{*}{$(60 \%)$} & 0.00 & 17.08 \\
\hline & & 0.00 & 18.35 \\
\hline & & 0.00 & 16.29 \\
\hline \multirow{3}{*}{$P_{v-2}$} & \multirow{3}{*}{$(70 \%)$} & 11.48 & 18.94 \\
\hline & & 8.66 & 21.53 \\
\hline & & 10.04 & 18.42 \\
\hline \multirow{3}{*}{$P_{v-3}$} & \multirow{3}{*}{$(80 \%)$} & 11.27 & 24.33 \\
\hline & & 10.63 & 27.28 \\
\hline & & 13.05 & 30.83 \\
\hline \multirow{3}{*}{$P_{v-4}$} & \multirow{3}{*}{$(90 \%)$} & 14.55 & 27.54 \\
\hline & & 14.82 & 32.43 \\
\hline & & 16.14 & 30.72 \\
\hline
\end{tabular}

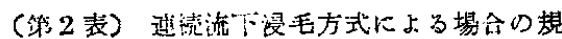
定特间 ( $5 \mathrm{~min}$ ) 飞和计了多孔度, 注削温度 の組合せに上る洼出液量 $\left(V_{\rho}\right)$ の揤定結果 (単位 $\mathrm{cc}$ )

\begin{tabular}{|c|c|c|c|}
\hline 多孔度 & 注成渴度 & $T_{e-1}\left(22^{\circ} \mathrm{C}\right)$ & $T_{e-2}\left(60^{\circ} \mathrm{C}\right)$ \\
\hline \multirow{3}{*}{$P_{v-1}$} & \multirow{3}{*}{$(60 \%)$} & 0.0 & 9.2 \\
\hline & & 0.0 & 9.8 \\
\hline & & 0.0 & 8.0 \\
\hline \multirow{3}{*}{$P_{v \sim 2}$} & \multirow{3}{*}{$(70 \%)$} & 12.0 & 46.5 \\
\hline & & 10.5 & 52.2 \\
\hline & & 7.5 & 45.3 \\
\hline \multirow{3}{*}{$P_{v-3}$} & \multirow{3}{*}{$(80 \%)$} & $63 . \overline{4}$ & 313.7 \\
\hline & & 58.2 & 126.5 \\
\hline & & 73.4 & 167.8 \\
\hline \multirow{3}{*}{\multicolumn{2}{|c|}{$P_{v-4} \quad(90 \%)$}} & 185.0 & 356.8 \\
\hline & & 196.5 & 411.2 \\
\hline & & 218.5 & 393.0 \\
\hline
\end{tabular}

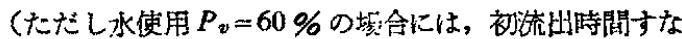
わち試料圆通過時閵は $5 \mathrm{~min}$ 上上を姴するので, 流出 液は觜然であり $\eta_{f=0}=0$ である） いまこれらを原表と して二元配置による分散分析を行ってみると，第 $3 ， 4$ 表汇示すことき分散分析諘を得る。として $F$ 分布婊に

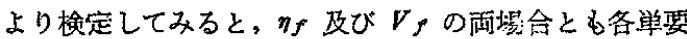
因及びその交互作用はいずれる1\%有意となりこのよ 5 に流時時閒を規定して実際漫毛工程に近似させた流、 漫毛方式に上った場合に，多孔度，使用水温度がその效

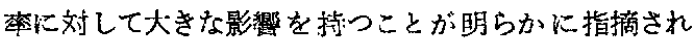

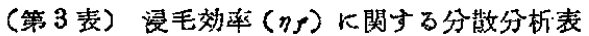

\begin{tabular}{|c|c|c|c|c|c|c|}
\hline 要 因 & S.S. & $\phi$ & $V$ & $F_{0}$ & $F_{(0.05)}$ & $F(0.01)$ \\
\hline$T_{e}$ & 1246 & 1 & 1246.0 & $401.9 * *$ & 4.49 & 8.53 \\
\hline$P_{v}$ & 624 & 3 & 208.0 & $76.1 * * *$ & 3.24 & 5.29 \\
\hline$T_{e} \times P_{v}$ & 101 & 3 & 33.7 & $10.9 * *$ & 3.24 & 5.29 \\
\hline$S_{t}$ & 1971 & 7 & 281.6 & & & \\
\hline$S_{n}$ & 50 & 16 & 3.1 & & & \\
\hline 許 & 2021 & 23 & & & & \\
\hline
\end{tabular}

(第 4 表）流出液量 $\left(V_{f}\right)$ K関する分散分析表

\begin{tabular}{c|r|r|r|r|r|r}
\hline 要 因 & \multicolumn{1}{|c|}{$S . S}$. & \multicolumn{1}{|c|}{$V$} & \multicolumn{1}{|c|}{$F_{0}$} & $F_{(0.05)}$ & $F_{(0.01)}$ \\
\hline$T_{e}$ & 34.884 & 1 & 34884 & $144.1 * *$ & 4.49 & 8.53 \\
$P_{v}$ & 313488 & 3 & 104.496 & $431.8 \%$ & 3.24 & 5.29 \\
$T_{e} \times P_{v}$ & 22418 & 3 & 7472 & $30.9 * * *$ & 3.24 & 5.29 \\
\hline$S_{t}$ & 370790 & 7 & 52970 & & & \\
$S_{V}$ & 3871 & 16 & 242 & & & \\
計 & 374661 & 23 & & & & \\
\hline
\end{tabular}

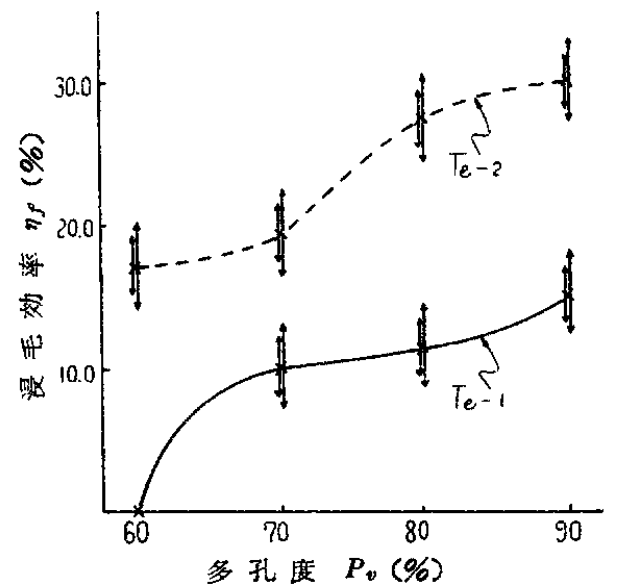

（第4、四）連䋶流下浸毛方式に上る場合の规定

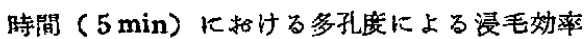
の变化（注削温度による相遣を示す，矢印の左

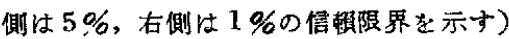


る. いま要因 $P_{v}$ の各水淮につき，平均値によって信 賴限界を指定して クナの变化を四示してみると第 4 园

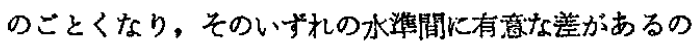
かを挨定するために，各水準の母平均の差の梌定を行 ラ. すなわち測定䊅果の各組合せの平场値をもってなす 壦合

$$
\begin{aligned}
& d_{\alpha}=\sqrt{\left\{F_{\varphi_{N}}^{\prime}(\alpha)\right\} \cdot 2 \cdot V K \cdot \frac{1}{\pi}} \\
& \varphi_{E}: \text { 歌盖項の自由度 } \\
& \boldsymbol{\alpha}: \text { 有意水潐 } \\
& \bar{n} \text { ：ある水淮に含まれる測定値の個数 } \\
& V_{E} \text { : 誤差项の不涺分散 }
\end{aligned}
$$

によって示される $d_{\alpha}$ よりる各水準間の盖が大であると き，その水準開に差があることになる、これによって $d_{a}$ を求めてみると $d_{0.05}=3.04, d_{0.01}=4.20$ であるか ら, 常温水使用の埸合は $P_{\boldsymbol{v}-\mathbf{2}} \sim \boldsymbol{P}_{\boldsymbol{v}-3}$ の間化は差がなく, $P_{v-3} \sim P_{v-4}$ の間に $5 \%$ 以下の有惢性で差があり,

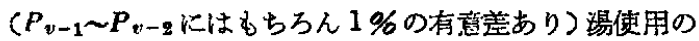
场合は $P_{v-1} \sim P_{v-2}$ 及び $P_{v-3} \sim P_{v-4}$ には差がなく， $P_{v-2} \sim P_{v-3}$ の間に $1 \%$ の有缹差が認められる.このよ らな結果から判断すると，大勢として水及び湯のいずれ の晹合も多孔度の大なるほど浸毛効楽は增大寸るが，特 汇晹使用の㳦合には $P_{v}=80,90 \%$ に捄いて良い結果を 示した。これは要するに规定時間 ( $5 \mathrm{~min}$ ) 以內に採取 される流出液量 $\left(V_{f}\right)$ は，第 5 図に示すごとく多孔度の

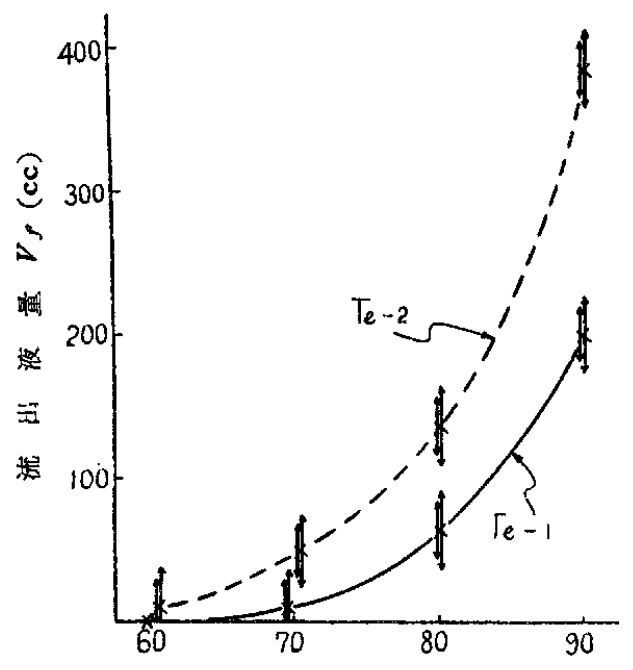

多孔度 $P_{\boldsymbol{v}}(\%)$

（第 5 四）連続流下浸毛方式火上る場合の規定

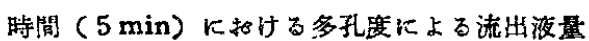
の变化（注削温度に上る相違示与. 矢印の布

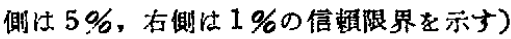

大なるにつれて急増し，特に湯使用の荟合に大きいこと と、肖傾によって明らかなよ5に，流下挑出作用が継綂 的であることに基く、しかるに常温水を使用した塯合 は，たとえ多孔度を相当大としても目立った効果はない ということになり，VP增加割合はどには多孔度によ る $\eta_{f}$ の增大はみられなかった。これも前垻の結果によ ってわかるよ5に，水を用いた塂合は多孔度の大なる㳗 ど排的絕対最は少なく，しかも流出被斯にのみ漫毛效果 があるが，以後はほとんど首色が認められないといら理 由によるのである。しかし常温水を使用して流下式浸毛 を行万剒合でも，士砂，しんあい等の湿在不純物を除去 する目的を同時に十分果すためには，やはり多孔度を大 としてV゙f の增大を図らねばならない。

同様にして採取流出液量 $\left(V_{\boldsymbol{P}}\right)$ につき园示してみると 第 5 図のごとくなり，この堎合は $d_{0.05}=26.9, d_{0.01}=$ 37.1 であるので，常温水使用の堎合は $P_{v-1} \sim P_{v-2}$ の 閒にのみ差がなく，他の水準閏には全部 $1 \%$ の有意誈 があり，また湯使用の晹合はいずれの水準間仁も1\%有

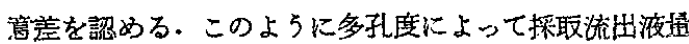
は大きく根違し，前述のごとく特に湯使用の塔合漫毛效 率に対して影瞕を及结す。

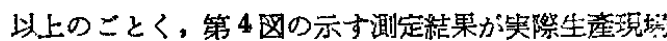
の Maloard 漫毛機に淤ける漫毛效猝を表現しているこ とになり，原毛塊の多孔度を大として給毛すべきことが 明らかな必姴条件である々指摘されるが，またいずれの 多孔度に扰いてひ温湯を使用する方が排出絶対量を增加 させ漫毛効率を上げる結果を意味している。乙かし浸毛 処理に㧍いてあまり高温の湯を用いると、グリ一ス分が 触解しればってくるために，次の洗毛そうに投入した塔 合羊毛塊が凝集する状態となり，洗毛效果の上から好ま しくない結果をきたすので，この点からかえって常温水 を用いてスイントのみを漫毛抽出の対象として行のた方 がよい（クアは少し劣化しても）との意兒もあるようで あるが、この点に関しては洗毛部門に扔いて検討する予 定である。

また使用水温度の漫毛効率に及ほす影㩰につき，より 詳細な湘达は，温度管理の完全になし得る浸せきう式の 塔合につき続報において報告する。

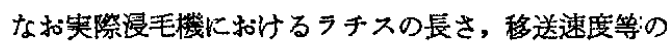
敬計资料として，標潐多孔度 $P_{v}=80 \%$ に执いて規定浸 毛時闒の他の㪚合について㵋定しな結果を第6図に示 す. (备3 回測定の平均值をもって示寸)すなわち注水 開始よりの経過時閒 $T_{i}=3,5,7,9,11 \mathrm{~min}$ の各晹合につ 


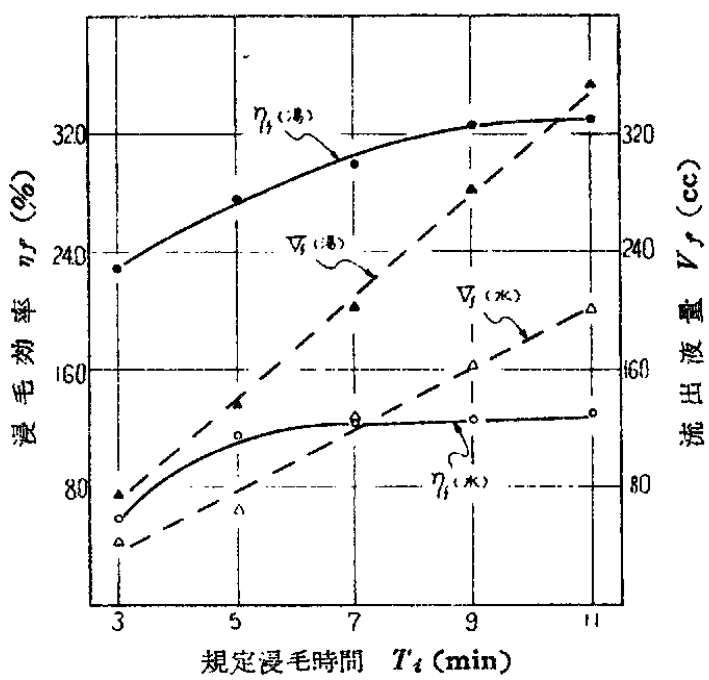

(第6困) 規定㭙間の相遠による浸毛效率の变 化（摽隻多孔渡 $P_{v}=80 \%$ 埸合）

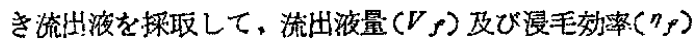

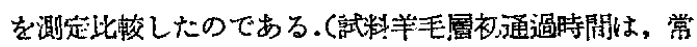
温水及び湯の車场合とも $1 \mathrm{~min}$ 以上を姴すつこれにより てかかるように $V_{f}$ は雨塂合とも植線比例的に增大する が、”のはをれぞれ貲なった傾向を示し，常温水(22士

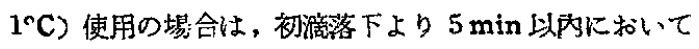
次第に排出ヨーク量を増し好率は大となるが，それ以上 流出を継続しても好果はなくはとんど一定値をとるよ5 になり，本奏験方式に执いて常温水使用に上る流下式漫 毛の場合は $\eta_{f}=13 \%$ 程度を限度とすることを示してい る.また温湯 $\left(60 \pm 2^{\circ} \mathrm{C}\right)$ 使用の場合は， $T_{i}=9 \mathrm{~min}$ ま では次第に排出舅を增し効率は增大するが，やはりそれ 以上の継続処理は無意跦なようである。これらのことは

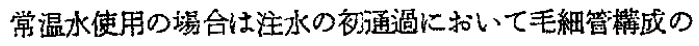
うち特大の空げきを選んで流下する傾向があり，しかも 以後あまり新䙺の通路開拓のないことが源因であり，温 㵀の境合はこの点経過時間とともに少しすつ羊毛塊中の 漫洞が進行し，新規通路の開拓が行われグは增大する

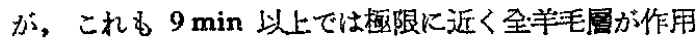
を受ける状態となるためと思われる。

ゆえに漫毛機ラチスの長さ，移送速度等は，生锖能率 上からむ羊毛塊に対し必要以上の被处理時間を与えなく ても良いことになるが，しかし本実験においてはヨーク 分のみを対象としての考察であるが，実際浸毛処理に拈 いては土矽等固形不純物の排出妨果を增すことも考慮さ れ根ばならな。

\section{6. 原毛昷の相䢖による効率の変化}

すでに第1 報において，羊毛尿厚さによる初流出時
閶. 流出量の相違につき考察したが，このように潜下方 式による漫毛好理において，同一多我度の埸合です話料 原毛量の多少によって漫毛效察は同一ではないと子想さ れるので、この点につき測定した。

すなから $1 \mathrm{~cm}$ 管を用いて, $1.17,3.52,5.89,8.22$ ， $10.56 \mathrm{~g}$ (無水量は $1,3,5,7,9 \mathrm{~g}$ となる) の試料をそれ それ 4.9, 14.7, 24.5, 34.3,44.1 cm 高さに充てんし。 いずれる同一標準多孔度 $P_{v}=80 \%$ を得た。この堎合 に扎て水 $\left(22 \pm 1^{\circ} \mathrm{C}\right)$ 及び湯 $\left(60 \pm 2^{\circ} \mathrm{C}\right)$ の $50 \mathrm{cc}$ を 常に水位が試料上面より $10 \mathrm{~cm}$ 位置（水任 $10 \mathrm{~g} / \mathrm{cm}^{2}$ ) を保つように連続注水し，排出流下完了を待って漫毛液

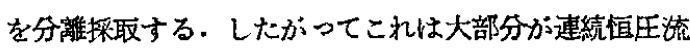
下によるが，最終部分のみ淢壬流下によることになり。 注剂比 $(\alpha f)$ も求めることができる。

实験絃果とその考察

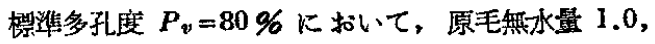
$3.0,5.0,7.0,9.0 \mathrm{~g}$ の各场合につき水及び禓を詝いて 測定した結果を第7四に示す。

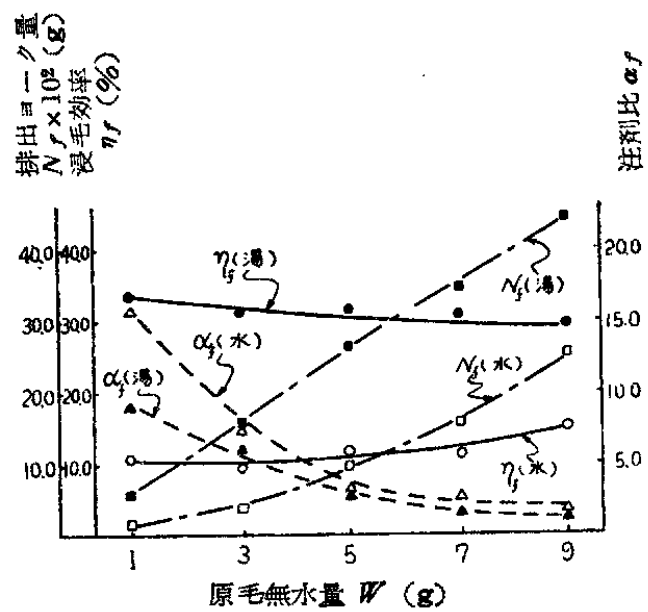

（第7四）娍下漫毛方式に上る場合の原毛量の

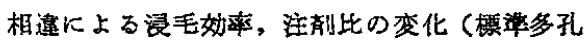
度 $P_{v}=80 \%$ の埸合)

まず各埸合の全排出固形ヨーク量 $\left(N_{f}\right)$ をみると，む ちろん原毛雵の堌加にとるなって堌大し，水, 湯の耐場 合において同様な增加傾向を示す。そして各原毛量にお いてやはり激使用により排出絕対量は水の嚗合の 2 倍以 上を示したところがこれを原毛含有全ヨーク量に対す

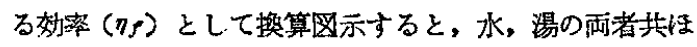
とんどー定の值え示し，原毛量による变化はみられな いこれは注剤比 $(\alpha \rho)$ 变化についてみられるごとく， 原毛量の增加するにしたがって秥は小となり，滞単水 量の多く流下排出量の少なくなることがわかるが，また 


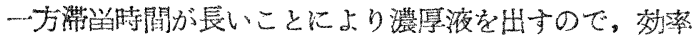
的には变らないことになる。そしてこの $\alpha_{f}$ は原毛量の

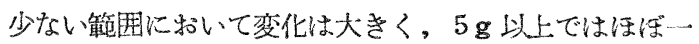
定值を示す。またいずれの原毛量汇おいてる水使用の境 合の力が大きな值を示し，湯の塂合は流出量の少ないこ とがわかり第 1 報の結果と一致する。すなわち $\alpha=1$ と いうことは。注水量の半分近くが滞的することを意味す る.

さらにこれら $\eta_{f}, \alpha_{f}, N_{f}$ の測定結果を, 原毛層厚 さ (h) によって図示してみても第7図と全く同様の傾 向となり，供給厚さについても同様な考察がなり立つ。 このように流出肵要時䦓を考慮しないならば，效率的に は原毛量によって変化がないことになるが，しかし同一 多孔度でも原毛量の多い注ど初流出（通過）時間 $(t)$ は 長く, 单位時閵に和汁る流出量も少なくなり, 前項のご とく実際作業にお斿る漫毛機ラチス上での被浸毛時間と しての規定時間內の効率はきわて惠くなる. 本項及び 第 1 報の湘定結果から判断すると，本実験の劫合 $W=$ $5 \mathrm{~g}$ までを限度とし，上く開毛されている $P_{0}=80 \%$ 以 上の場合に蛙いて $h=25 \mathrm{~cm}$ 以內であることを要する。

したがって生産高を增さんがための必要以上の供給過多 は不適当であり，後続の洗毛処理の負担を大とする結果 になることが指摘できる。

\section{7. 結曹}

以上の流下浸毛方式化基く場合の諸項の実験紶果から Maloard 浸毛機に打计る漫毛效摔として総合的に判断 するならぱ、排出效果を上げ能率を增進させるための必 要条件としては
（1）多孔度をできるだけ大として㖼給すること

(2) 適当な温度の湯を用いること（前述の洗毛機構 に持㐨る間題点は別として)

（3）ラチス上への供給羊毛署の厚さを限度內とする こと

（4）注水量，ラチスの移行速度が適当であること がくり返し強調される。そして本実験に拈ける測定はヨ 一ク分のみを対象としており, 試料羊毛は土砂その他の

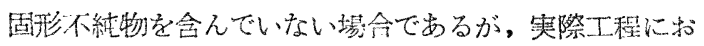
いてはこれらるまた大きな漫毛作用の対象物である。い えにこのような観点からすればより一膡多孔度の大な ることが必劕条件として要求されることになる。

本実験実施汇当り，格別の御指導を得た東京工大教授 石川章一博士並びに種々御便宣を与えられた大和毛織嘲

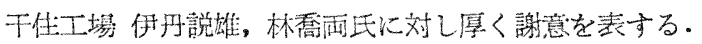
また実験に協功された筒井清次郎君に感謝する。

な扮本報の要吕は31年度秋季研究発表会にお、て発表 した。

\section{答交献}

1) 著者: 第 1 報, 本誌, 8, 5 (昭30-5) P. 10

2) 著者: 第 2 報, 本誌, 8,10 (昭30-10) P. 14

3) 著者: 第 3 報, 本誌, 9, 1 (昭31-1) P.27

4) T. Vickerstaff : The Fhysical Chemistry of Dyeing, P. 31 (1954)

5) 安藤 : 染料膠賢学, P. 137 (1940)

6) H.W.Wolf, R.S. Rankl : Am. Dyes. Rept., 42,617 (1953) 